\title{
Heritales 2017 - Beyond the academia. Re-thinking Heritage trough cinema and others art forms
}

\author{
Maria Zozaya-Montes \\ CIDEHUS - Universidade de Évora, Portugal \\ Nicola Schiavottiello \\ CIDEHUS - Universidade de Évora, Portugal
}

\begin{abstract}
The UNESCO World Heritage city of Évora (Portugal) hosted the second Heritales - International Heritage Film Festival in September 2017. In this edition the festival focused on current and past sustainable communities, selecting works that explored and problematized the relationship and coexistence of modernity and sustainability when applied to human groups and societies. The films presented the everyday life, knowledge, crafts and know-how of ordinary people highlighting the changes and challenges that the expansion of consumer-based economies, globalization and world politics have brought. As organizers, by focusing on sustainability in heritage context, we wanted to go beyond current preservation strategies of the tangible and intangible heritage, to promote a reflection on the "culture of sustainability" itself, looking at how sustainable waysof-existence have characterized various communities and cultural practices worldwide. Since its first edition, the festival has been a space for the promotion of a critical understanding of cultural heritage, aimed to the broader public. By using emblematic historical places as stage, Heritales has challenged the mainstream cultural heritage scientific communication. Its proposal is to approach heritage's issues through multiple types of media and artistic work such as films and documentaries but also cultural heritage's games, exhibitions, theatre and performance, with talks and several communication strategies to facilitate the encounter between the authors and the public. Although the festival has received many positive feedbacks and the support of various entities such as the UNESCO Chair of the University of Évora (Portugal) and the FCT (Science and Technology Foundation, Portugal) it is still at its early stage of action. In this paper we would like to present the results of our experiment and analyse its concept and results, so that more collaborative and sustainable methodologies can also become a part of our plan of action for the organization of future events.
\end{abstract}

Keywords: Cinema, Heritage, Sustainability, Cultures, Academia

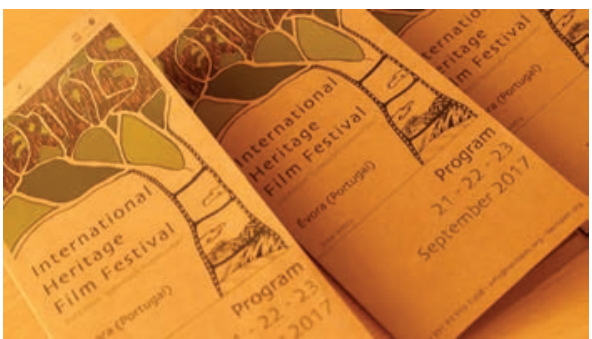

Figure 1- Program pamphlet Heritales 2017.

\section{Introduction: State of the art. Heritales as the renewal of the social sciences}

Heritales is a strategic project in the Social Sciences, it focuses on the importance of the renovating poles of recent decades. Its strategic location between leisure time, together with its commitment to the new supports for didactics (among which the cinema stands out), place it as an innovative pedagogical proposal within the academy.

Regarding leisure, it is a double-edged pedagogical weapon: under the innocuous appearance of an unused wasted time, it allows to develop issues of great importance in the educational field.

Leisure was considered banal in appearance for the social sciences during the 20th century, so much that it was even called "the foam of history" (Pieper, 1989). During the 21st century, it has been remarkably revalued in Western society, and also in the social sciences. The academic innovation that took place with the French School of the Annales since 1930 is therefore essential. Especially when Lucien Febvre remembered in his Combats for History (1952) that one could not try to continue making a positivist, supposedly scientific History when the classical postulates that governed the assumed universal scientists had collapsed. This was reaffirmed by Thomas Kuhn when he explained the fall of the classical paradigm with the scientific revolution and its impact in the field of social sciences (2001). In this revolution, some authors stand out supporting the value of leisure. Johan Huizinga (1972) had stressed the importance of the role of leisure in culture as a key element for the development of Western civilization. Sebastián de Grazia (1966) showed how leisure practices were not exclusively recreational and how they were inherent in the welfare society, even though bourgeois society tended to separate them from work (Dumazzedier, 1962). The greater openness towards leisure studies would come from the hand of the Mai 1968 and the thematic explosion of the subjects of 
the social sciences, that would put an end to Clio's totalitarian attempt (Dosse, 1988, 1995). In the field of leisure, appeared the studies of Maurice Agulhon $(1968,1977)$, revaluing the role of sociability for political life in the 18th and 19th centuries. Since the year 2000, numerous interdisciplinary studies have addressed the role of leisure for society in a broad sense from the Cultural perspective, and focus on its new possibilities. The most outstanding in didactic of the social sciences is probably the line that applies to games for learning, through the so called "gamification" (Stott, 2013, 1-8; Dicheva, 2015, 11-19).

Our hypothesis is that leisure is an element that has been relegated by the influence of the culture of work during the development of capitalism. In the 19th century, leisure was devalued by the impetus of bourgeois opposites values that praised the work along with the meritocracy, perseverance, application and savings of the development of capitalism itself (Zozaya, 2008). At the same time, the economically disadvantaged groups were assuming those same principles. From the 19th century, among the groups of workers, work was seen as the only way of prospering, in the face of the clear salary and professional disadvantages brought by labour abstinence in the leisure time at the tavern (Thompson, 1984). These ideals were created from the intellectual bourgeoisie and assumed by the rest of the groups that trusted in the social ascent on the basis of merit. Precisely, that group took the power of the University in the nineteenth century, which ended up building Science for the bourgeoisie (Capel, 1983). In our opinion, these bourgeois values probably coming from the theories of Positivism Ranke's (Fevre, 1952, 41-51) prevail to this day, marking the excessive valorisation of the precepts of the work culture to the detriment of the value of leisure, with the supports that is associated with: games, theatre, cinema, and so on. However, Heritales stand for the educational role that these are constituent parts of culture.

To understand the revaluation of leisure we must remember voices that rescued its importance at the end of the 19th century as Marx's son in law (Lafargue, 1880). Some theorists expressed how ostentation of leisure was a way of reflecting social power among the upper class (Veblen, 1889). The privileged class made extensive use of leisure to externally project its signs of power in society, while helping to build a part of the bourgeois identity (Zozaya, 2016). Part of that identity was based on the construction of the Cultural Capital (Bourdieu, 1989), with the organization of events that, more than teaching, sought to build a scientific profile of the cultured bourgeois (Martínez, 1991).

Without seeking the prestige of leisure, but directly contemplating its cultural possibilities, several experiences in the Iberian Peninsula can be highlighted, because they blend entertainment activities with didactics. The most relevant arose from the attempt of the pedagogical renovation of the Institución Libre de Enseñanza (The Free Institution of Education) inspired by the tendencies of German Krausism movement between 1880 and 1936 . There was born the theatre of La Barraca, where intellectuals like Federico García Lorca went through the Spanish villages representing dramatic plays with didactic purposes. Years later, the phenomenon of the teleclubs can be highlighted in the same line. Churches, work centres or social houses that served to give cultural notions to groups with less cultural possibilities became cinemas. These experiences were favoured by social scientists such as Joffre Dumazzedier (1970), who helped to extend the principles of support for schooling and the promotion of culture among groups of workers. In our opinion, with that experience, based on leisure, its possibilities were shown to favour training activities. From that moment when the show was integrated into the didactic for citizenship the fourth theatrical wall of the bourgeoisie began to fall, where any street building could contribute to the school of citizenship, just as they have done other intellectual movements (Álvarez, 2012).

In the aforementioned sense of changing the paradigm (Kuhn, 2001), Heritales proposes to democratize the transfer of knowledge and put the university outside the bourgeois domain. It surpass the university's walls to reach all citizens, during their leisure time. In this sense, after two editions, Heritales has been internationally quoted as one of the most integrative proposals of the city (C. Casonato, 2016: 774, Taxi Driver, 2017: 36). This reveals the need to make the heritage come through film festivals, whether exclusively scientific or with social remark.

\section{Festival Concept}

The International Heritage Film Festival - Heritales started as a project framed in the research of new technologies in heritage communication of Nicola Schiavottiello, as well as in the studies of leisure and sociability of Maria Zozaya.

Through this festival we seek alternative ways of disseminating science, using tools that can be very useful for a broader education and far reaching knowledge transfer. This form of engagement reveals the need to rescue aspects that are often ignored by scientific events. Among its objectives, it advocates for the renewal of knowledge transfer in the academic world and beyond. It insists on the importance of showing material and immaterial heritage through media such as cinema, games, exhibitions and installations and inviting authors to give talks, lectures and workshops in emblematic heritage sites. Thus, it allows to deepen in the didactics and impact through the promotion of different languages and spaces besides the traditional conferences found in the academic world.

Since the first edition in 2016 Heritales has created a meeting point for truly interdisciplinary international investigations into tangible and intangible heritage (Schiavottiello \& Zozaya-Montes 2016). It has been able to bring together several essential elements of the UNESCO 2030 program: sustainability, tangible and intangible heritage, and the cultural awareness of the community. In 2017 it was decided to choose "sustainability", within the sub-theme of the festival, not 
as a noun but as a substantive of past and present "communities". In this edition, it focused on the role of community practices that gave birth to material and immaterial cultural heritage, as well as the implications of uninterrupted daily social relationships with surrounding objects. It received authors from all over the world that showed strategies of various communities to survive or adapt to modern or past fast progresses of a globalized society, with their respective inner problematic to the cultural change.

In 2017 the festival managed to unite in the public spaces (from Portugal and Italy) several forms of cutting edge knowledge's transmission: games, installations, photographic exhibitions, cinema (short films and documentaries), and conferences with their authors. Through these mediums and from a wide academic vision, it has managed to give more visibility to the scientific production on material and immaterial heritage. Besides, it has reached a broader audience of general public and researchers at the same time, bringing the academic production in social sciences to the streets, emblematic buildings, natural parks, historical associations, other festivals and non-conventional academic spaces and often using emblematic heritage sites (Fig.2).

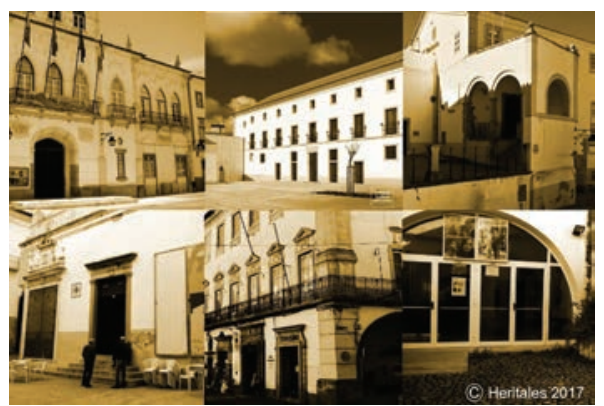

Figure 2 - Event's Places of Heritales 2017.

It is possible to affirm that, as in the type of theatre that takes away the fourth imaginary wall between the spectator and the public, Heritales pulls the wall that divides the academy between the professors, the students and the whole citizens. Moreover this second edition has fostered international synergies between Évora and multiple regions of the world.

The geographical reference frame chosen for the main sessions in the city of Évora allowed to give a comparative perspective on the South to the different scales: Iberian Peninsula, European, Asian, American and Brazilian. This city, within its 4 kilometres of enclosed wall, traversed part of the world heritage, permitting to discover the eastern and western cultures through public and private spaces and their ways to find a sustainable way of life to survive. Besides, heritage is one of the most important values in economic terms for tourism in Évora and Portugal, so the scenario of the festival, the walls of the city, became a very valuable canvas for the transfer of knowledge.

\section{Festival Methodology and execution}

The second edition of the Heritales - International Heritage Film Festival took place in different locations in Portugal and one in Italy, from May to December 2017, with the main event in Évora in September 2017. The full presentation of the events and invited authors can be found on our website: (https://www.heritales. org/wp/past-editions/home2017/). What follows is a summary of the most important events.

\section{Projections and debates}

A key element of the philosophy of Heritales is its interdisciplinarity, for which it invites multiple authors from diverse academic backgrounds in order to disseminate their research on different cultures. It concentrates on the ultimate significance of the topic chosen within heritage, which in this case, was the sustainable way of living of worldwide communities. The objective was, in fact, to coordinate debates in various areas of the sustainability of Heritage related to collective know-how from a social, ethnological, historical and anthropological point of view.

Among all the invited and selected filmmakers we can highlight the awarded works that best illustrates the scientific objectives of Heritales. A key representative filmmaker was Vicente Pérez Herrero (author of shorts and feature films in documentary and fiction, and several times nominated for the Goya awards in Spanish cinema) presented his upcoming documentary "Amazonia y Utopia" (Fig.3), after the award ceremony.

This documentary recalls the story of the Jesuits that attempted to rescue from oblivion a unique experience to achieve a just society in the Amazonia and to link this utopia from 1600-1750 with the defence of minority ethnicities, fair trade, and respect for nature (Herrero, 2016).

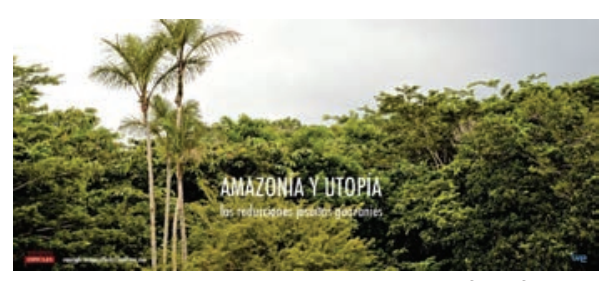

Figure 3 - Amazonia Y Utopia poster by Tiempodificilesfilm.

The winner of the 2017 edition long length documentary, Ildiko Plajas, with "Swamp Dialogues" (Fig.4), for which she has gained the UNESCO's award in 2015 . 


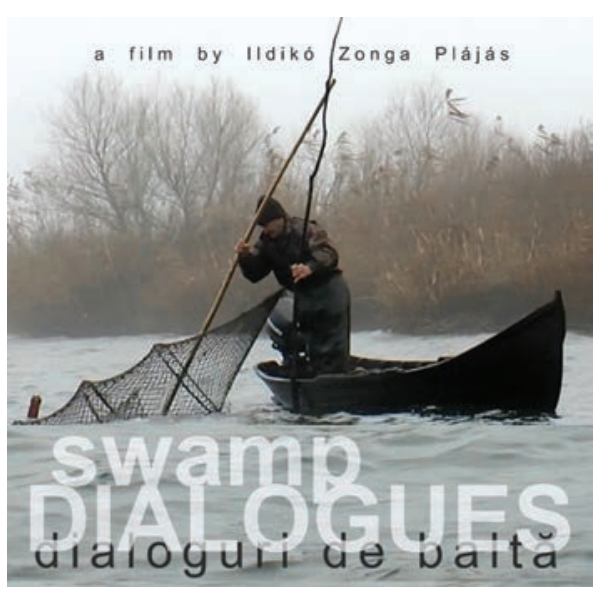

Figure 4 - Swamp Dialogues Poster by Ildikó Plájás.

In this wide portrait of the delta of the Danube river, the public is confronted with the dilemma of the effort to protect the biodiversity of the area and the endurance of the locals who struggle to survive against the directives of the UNESCO's Natural Reserve. The winner of the short length documentary Begoña Aramayona with Next stop: "La Latina", a film that speaks the voice of the inhabitants of a central neighbourhood in Madrid, where gentrification and tourism have drastically changed the asset and their life. The work by Jenny Chio, a university teacher of anthropology at Emory University (USA) and author of the Chinese rural life film "Peasant Family Happiness" (Fig. 5), for which he won the David Plath prize in 2013.

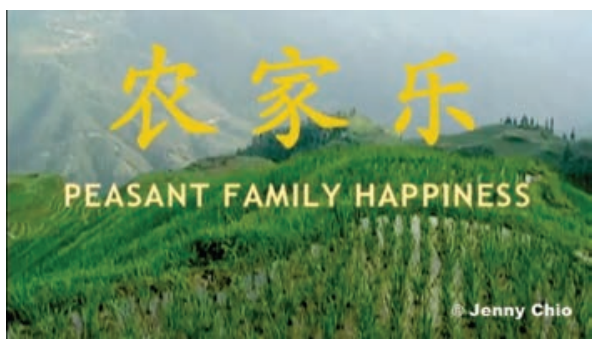

Figure 5 - Peasant Family Happiness by Jenny Chio.

Marcia Mansur \& Marina Thomé with "The Sound of Bells" (Fig.6), that show a portrait of the action of the bell ringers that have mixed the colonial origin with the African traditional rhythms, introducing their heritage vision, as "a poetic representation of religious experience in everyday life" (Mansur, 2016).

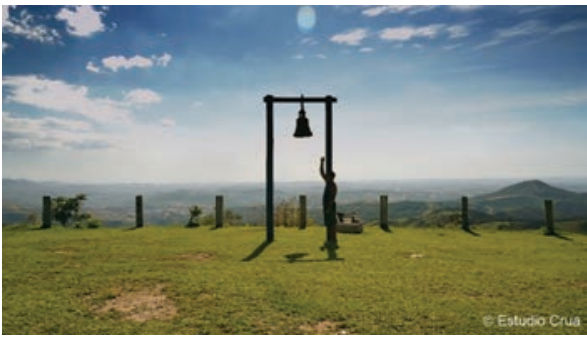

Figure 6 - Screenshot of Sound of Bells by Estudio Crua.

Finally Gianfranco Spitilli who presented "The Number of Steps" (Fig.7): in a remote village on the Italian Apennine, Antonio Moretti, one of the last great elder of his village, counts the number of his steps in order to move around the space where he lives due to his almost blind condition. This does not seem to bother him too much but instead is preoccupied with the human condition of the modern hectic life.

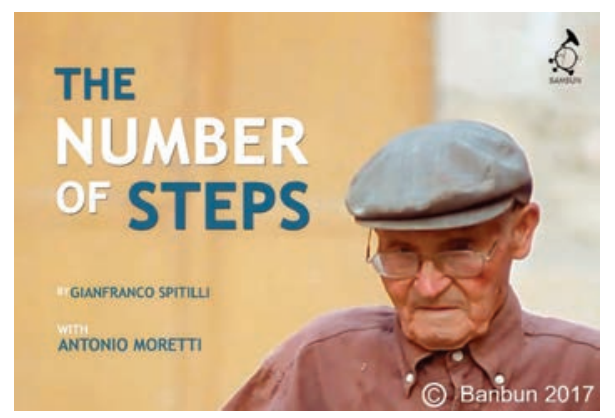

Figure 7 - The number of step poster by Giafranco Spitilli.

Linked to the biodiversity and natural sustainability we can highlight the following sessions: the documentary "Colori Profondi del Mediterraneo" (ISPRA) was projected in the Natural Reserve of Tor Caldara in Anzio (Rome, Italy). The impressive woodland setting of this projection where enhanced by the installation of the screen between two secular trees of the reserve. In this way the audience could appreciate the contrast between the sunset's colours and the strong subaquatic images of the documentary, showing the magnificent biodiversity of the Mediterranean sea (Fig.8).

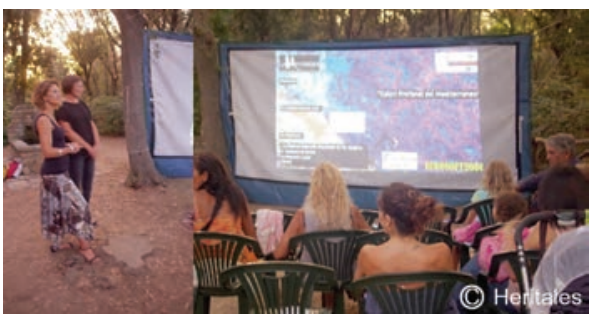

Figure 8 - Projection of Colori Profondi del Mediterraneo at Tor Caldara (Italy). 
At the Forum FEA, Nuno Beato, the director of Sardinha em Lata (a renowned Portuguese animation company), offered to show 5 short documentaries on the renewable energies of the oceans with "A descoberta dos Oceanos" (a project in collaboration with SNIMar - Sea National System of Information \& Sardinha em Lata, 2016). Nuno Beato repeated the workshop with the puppets he used to make this stop motion animation, also presented with Heritales at the EarthFest 2017 (Fig. 9), in the national Park of Monsanto (Lisbon, Portugal) (Fig.10).

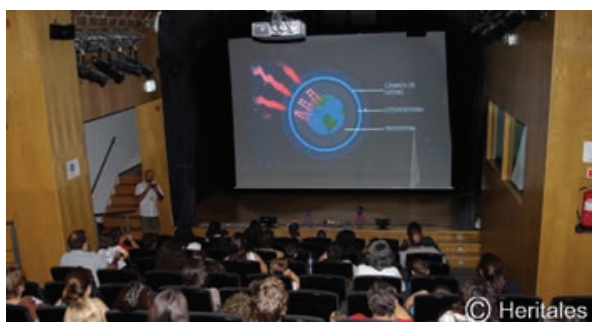

Figure 9 - Projection of A descoberta dos Oceanos at FEA.

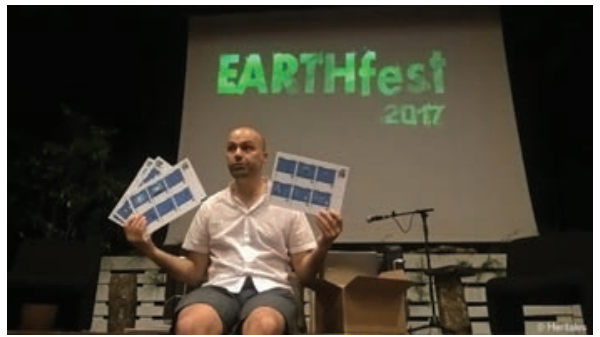

Figure 10 - Talk by Nuno Beato about the making of the film A descoberta dos Oceanos at Earthfest 2017 Photo: M.Zozaya.

At the Forum FEA was also projected "What a strange way of life" by director Pedro Serra during an innovative street art installation called Casa Animal. Here various forms of fine arts were presented in an installation shaped in a form of a house within an artistic container (Zozaya, 2017b) (Fig 11).

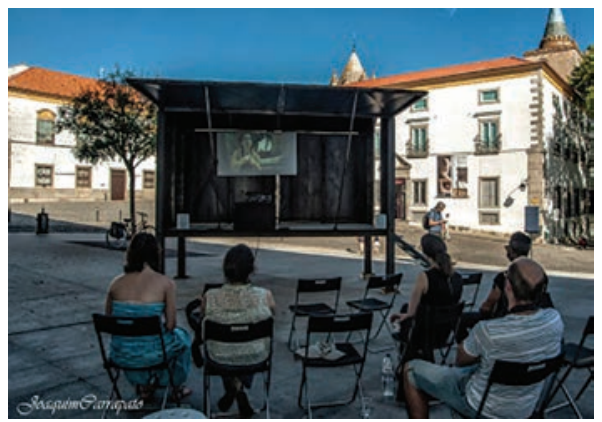

Figure 11 - Projection of "What a strange way of Life" at Casa Animal FEA. Photo: J. Carrapato.

\section{Exhibitions, installations, performances and talks}

Heritales started in 2016 with the idea of showing scientific research through cinema to the general public. Although this has remained the central part of the festival, with different awards assigned to the winners each year, it has evolved into other several activities. In fact, if in the first year, these were just an experiment by inviting the authors, in the second year they evolved into an essential part of the festival. In this section, we will describe how these actions have been relevant to the project. Eventually Heritales will try to merge all these different art forms that commonly are connected to leisure time (visual, performances, games, theatre) into one simple concept of "Heritage science throughout art \& leisure". As we introduced above, this is our method to break the intellectual talks that symbolize the wall dividing the academia from the citizens.

Since the first edition, Heritales was seeking for an event with interdisciplinary authors talking about heritage within different narratives, but always with a strong impact on image research. That is why the opening ceremony of this second edition of the festival was celebrated with the photographic exhibition "Olhares" which show the work of a Bronze Age archaeological site in Beja (Portugal) (Fig.12).

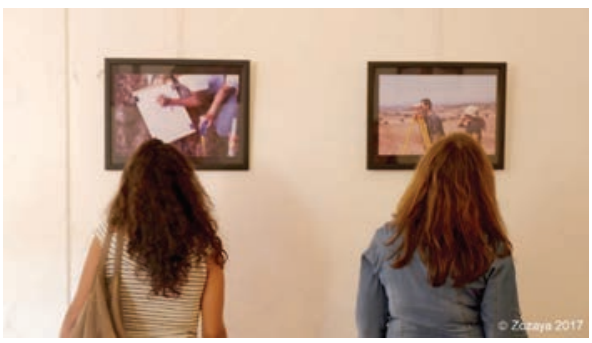

Figure 12 - Photographic exhibition "Olhares" by Outerio do Circo at GPE. Photo: M. Zozaya.

These stunning photographs showed the archaeological site Outeiro do Circo, one of the most important Bronze Ages settlement of Portugal, in Beja. The opening with this project, led by Miguel Serra and Eduardo Porfirio, became an optimal starter in order to create synergy between the invited different authorities of the city (DRCA, CME, CMB), private foundations (GPE, FEA, Forum FEA) and scientific representatives (CIDEHUS-UE and CATEDRA-UNESCO-UE) as well as the general public (Fig.13 - 14 - 15). 


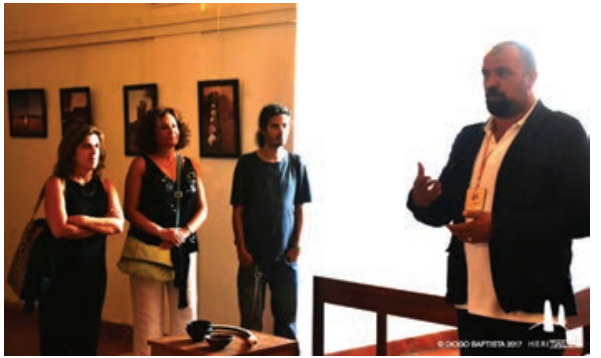

Figure 13 - Presentation by Miguel Serra of "Olhares " at GPE. Photo: D. Baptista.

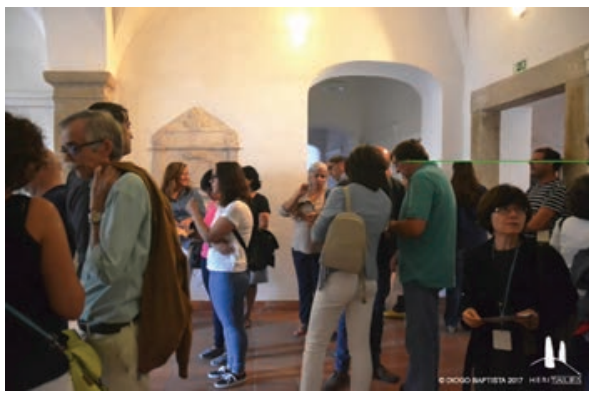

Figure 14 - Opening ceremony at GPE. Photo: D. Baptista.

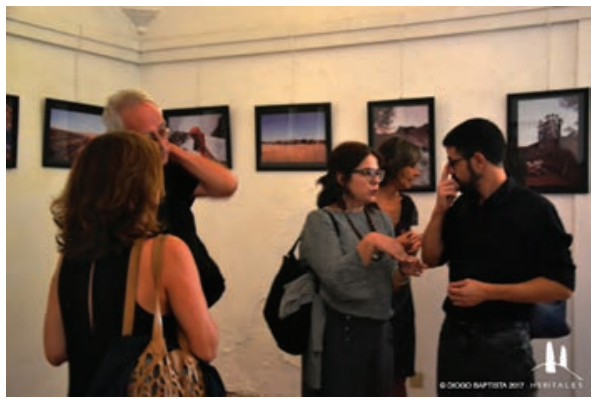

Figure 15 - Opening ceremony at GPE. Photo: D. Baptista.

Another challenge linked to new social engagement was to consider the introduction of educative videogames in our program (a small experiment was also done in the previous edition with the explorations of table games). In fact, as we pointed out above, Gamification has been shown as one of the most effective strategies in new education systems (Stott, 2013). This new research line was represented in Heritales with the conference and the practical session of Oxford University researcher Gabrielle Hughes called "Indigenous Videogames". She introduced the problematics related to modern videogames in western society: between the complexity of the legal system that it has been used in order to protect traditional knowledge, the heritage of the indigenous people, the cultural appropriation and the creation of the indigenous stereotypes, dominant in the collective imaginary generated by the west point of view (Hughes, 2017). Moreover Hughes presented here work done with indigenous people where she states that "although technology is often viewed as a threat to tradition, Indigenous video games offer a compelling example of the ways in which Indigenous communities and creators are harnessing and innovating in digital spheres, having an impact in both their communities and on the public perception of Indigeneity" (2017) (Fig. 16 - 17 - 18).

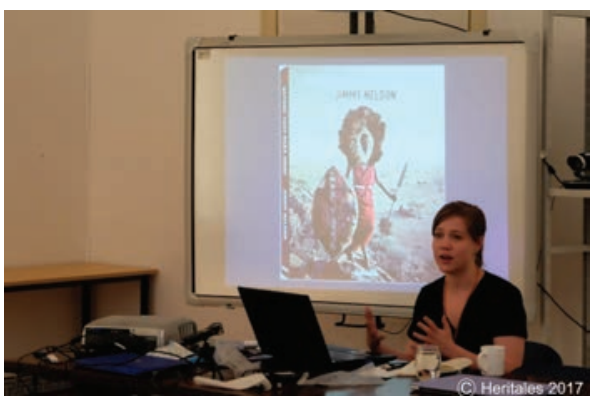

Figure 16 - Presentation by Gabrielle Hughes at Palacio Vimioso.

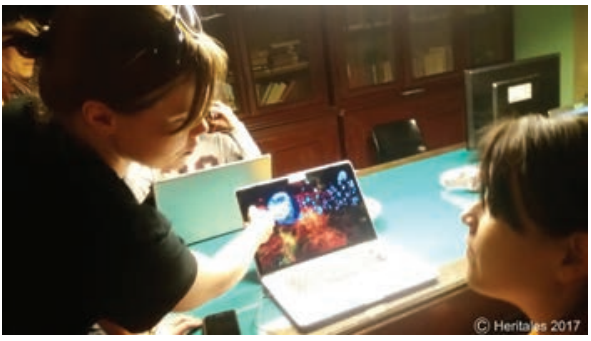

Figure 17 - Indigenous game activity by Gabrielle Hughes at SHE.

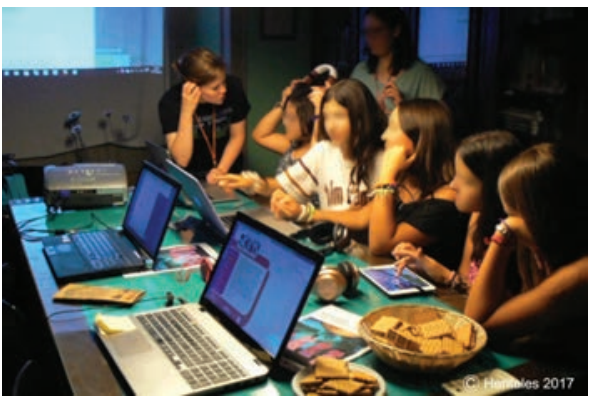

Figure 18 - Indigenous game activity by Gabrielle Hughes at SHE.

Finally we must quote three more ways which whom Heritales rescued intangible heritage through the visual arts. Firstly throughout meditation, with the help of the material element of art and symbols of religion. In this sense the installation "Transitions" explored immaterial 
culture of meditation in faith through the architecture of the Batalha's Monastery (Leiría, Portugal), with live music, and moving images (Barroso, 2017). While the film was first presented at the Residência Cisterciense in medieval convent São Bento de Cástris (Zozaya, 2016) (Fig. 19), the performative act was presented with the cinematographic support in the final show with the actors and the public of the festival, at the Sociedade Harmonia Eborense (a 19th Century Gentleman's Club), and (Fig 20).

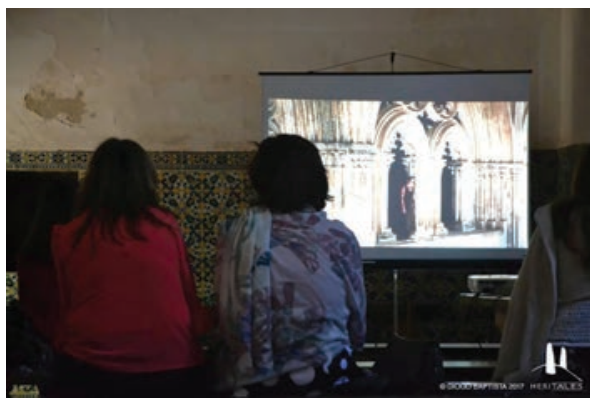

Figure 19 - Projection of "Transition" by Anna Barroso at Convento de Sao Bento de Castris.

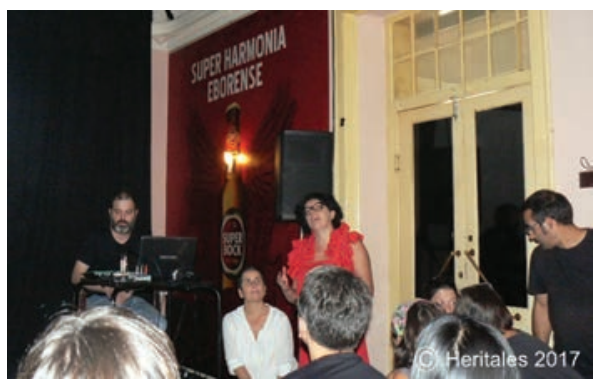

Figure 20 - Performance of "Transition" by Anna Barroso at SHE.

Secondly, "Past, Pass, Pasting" by Maile Colbert presented the woven relationship between human craft, the land and the soundscapes that those industries depend on. This audio-visual installation explores sonically and visually intangible heritage documentation, part of memory archives from rural areas from Tramontana European network (Binaural/ Nodar for the 2016 Viseu Rural 2.0) (Colbert, 2016). Thirdly, and probably the most challenging one, a theatre performance.

When interdisciplinarity appear in social sciences, the theatre is considered leisure for antonomasia, being one of the most forgotten sources by the academy (except for the thematic studies of literature and theatre). Heritales believes that this format can claim the multiplicity of discourse in the academia through the universal myth of the voice of orient and pan-European cultures. In fact, "Project OedipuS" (Fig.21), investigated, in a revisited visual version, the disappearance of the intangible heritage of the Greek myth of Edipus, which was rescued during the Middle Ages with the Arabic invasion of south Europe (Amiar, 2016). The same case of a classic work forgotten and rescued was proposed in the edition Heritales 2016 with the "Barokni Opera" by Forman Brothers, who used the Czech puppet's know-how tradition to rescue the musical piece of the Baroque period (directed by M. Janek and original idea by I. Arsenjev, P. Forman and J. Suchý).

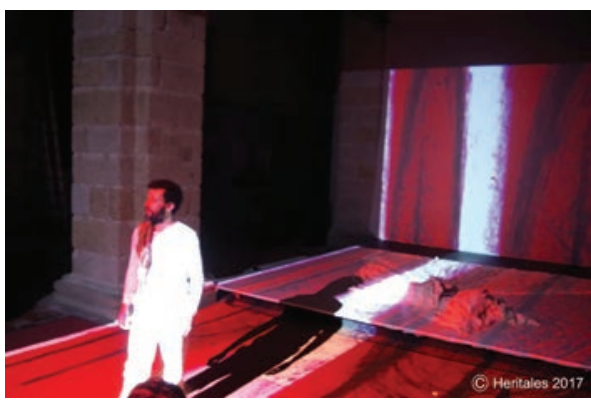

Figure 21 - Theatre performance by Souphiennne Amiar at Igrja de São Vicente, with Coleção B.

\section{Locations in historical buildings: watching heritage within heritage}

Another essential point of Heritales was to recover the Cultural height of the city heritage. In latest years History of Emotions has recovered a very important dimension of the past and the present, which is the affectivity. That part which was born with the contributions of French Annales School of Social History, became a constitutive element of the Social Psychology in the 1960's, and actually it was recovered in Cultural Studies. It is especially remarkable the symbolic meaning of Les lieux de mémoire (Pierre Nora, 1984), throughout which citizens modify its human action when they have the perception of the particular significance of a place. In this case, Heritales gives great importance to the affective meaning of the buildings which are representative of the history of the city, being part of its Cultural Heritage. The concretization of the film festival was in the Historical locations, which where accurately chosen from private to public spaces, from classic projection stages to non-conventional ones and from indoor to outdoor events, always with a special representation for the heritage of the city. We choose the Palace of Count Vimioso (Fig. 22), as the headquarter of Heritales, which has a symbolic links with the Humanistic Period. It is, in fact, a palace built during the period of the Expeditions, quite famous when Évora was the Court of Portugal. It is also remarkable because of the erudite Collection of Duarte de Bragança, and nowadays it is used as a research centre of the University of Évora (Miranda, 2013). 


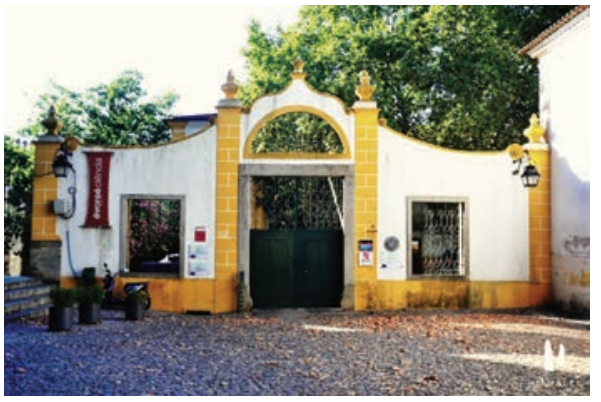

Figure 22 - Palacio Vimioso Evora.

Various sessions were organized in the historical house for gentlemanly capitalism groups the Sociedade Harmonia Eborense (SHE) (Fig. 23). This Society was created in 1849 for "members only", as a Republican Wing informal Association. It was the new centre of high class bourgeoisie leisure especially since 1902 , when they move to this historical building. Built in Early Modern Age, in a part of the city which in the 20th Century was to be reserved for the Gentry high class status, but since the Portuguese April Revolution in 1974 has been democratized.

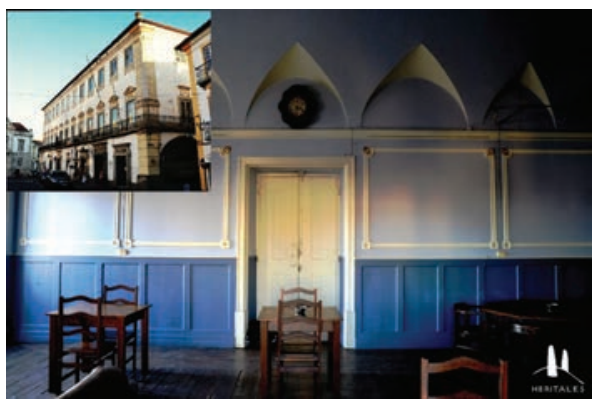

Figure 23 - Sociedade Harmonia Eborense, Evora (Portugal).

In the frame of looking at the city as a part of the heritage and at the same time location of the festival, an important component were the tours with film's directors and the public interaction. There has been in fact a lot of time dedicated to "heritage leisure", encounters, gatherings and sharing moments between all the participants. In this embedding atmosphere we should quote the two reception and presentation about the production and the different types of grapes. The first was given by Vinho do Alentejo (Fig. 24), this included a tasting of some of the regional wines that every week alternates in this reference point that to promote their products; and the second one given by Divinus Gourmet who kindly participated by offering not only the time for explaining all its regional products but also by offering the beverage for the meals of the festival.

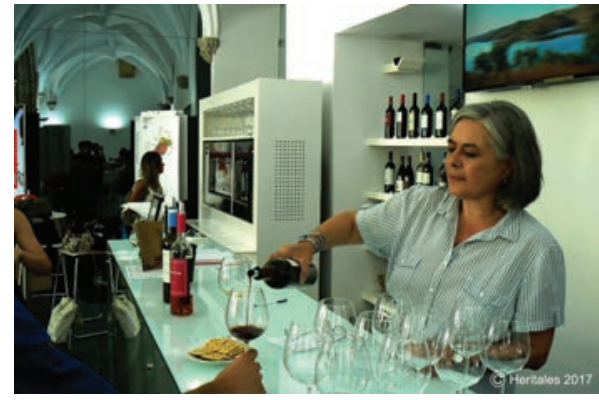

Figure 24 - Wine reception at Rota dos Vinhos do Alentejo.

The reception dinner was particularly an embedding moment of exchanging ideas for the international authors and FEA volunteers (Fig. 25).

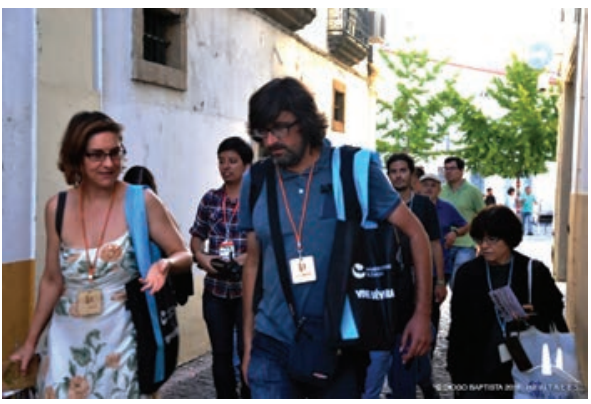

Figure 25 - Opening reception of the directors and other authors as Outeiro do Circo group at Grupo Pro Évora.

On Friday night, before the 3rd film session at the church of São Vicente the authors were invited at the Café Estrela Douro (Fig. 26). While the space in front of the church is usually occupied by late night student improvised leisure, this time it was given the possibility to be explored as an alternative space for culture.

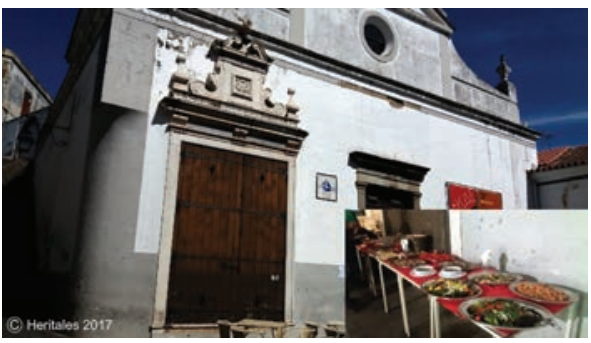

Figure 26 - Dinner at Igreja de São Vicente Evora (Portugal).

After the film session the night continued at the mentioned historical association, SHE, which hosted the Heritales party. The music was played by United Colors of Évora and Manuel Piçarra which alternated popular sounds from all over the world giving to the public a cocktail of quality music and the possibility to meet the directors of the films in a friendly atmosphere. 
All the authors were invited in the establishment of the DRCA (Regional headquarter of Culture) for a Saturday morning breakfast, accompanied by regional food products also offered by FerCarnes. Afterwards all the directors were given an inside of Évora with a tour of the city, kindly guided by Ana Cristina Pais, the superior technical responsible of the DRCA (Fig.27).

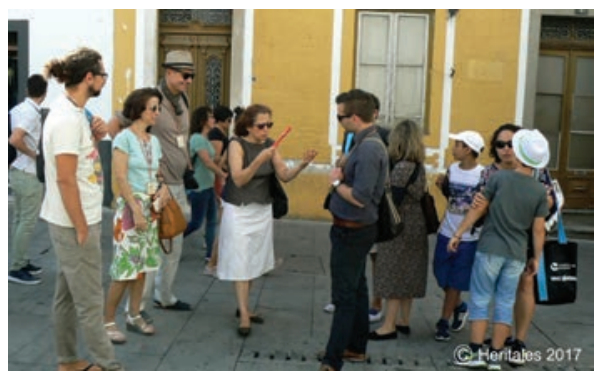

Figure 27 - Tour of Evora by Ana Cristina Pais of DRCA.

\section{Results. Practical issues of this model: Partnerships and impact.}

In 2017 Heritales expanded the following aspects whose growth had a greater impact than the 2016 edition. Summarizing, several new events were added, to explore the influence in other Portuguese regions; it expanded the geographical framework; the strategy in cooperation with national institutions; found more partnership with international institutions; enhanced the funds support: in the cultural private sector (FEA Forum), or achieving support that consolidates the scientific interest of the event by the FACC of FCT (Fundation for Science and Technology, Portugal). It placed a peripheral city at the tip of the world iceberg of the change of traditional pedagogical methods, from the University (CIDEHUS-UÉ, UNESCO-UÉ Chair), but also supported by some of the most relevant institutions of Alentejo (CME, FEA, DRCA).

The number of participating authors (and with them, the cultural heritage of the countries shown in the films) increased from the 2016 edition. Thirtyfive authors and directors showing heritage of Portugal, China, Nepal, Germany, Italy, Norway, Romania, Spain, Senegal and Canada. The outcome was many debates of high interest in multiple areas related to material and nonmaterial heritage and know-how. Subjects related to music, religious sociability, knowledge of trades and architectural spaces, social and relational assets. Several places where added to the program, as the festival expanded the geographical and institutional framework, collaborating with important events at regional or national level. So, besides the historical centre of Évora, it arrived in Lisbon (with EarthFest, 22nd of May), Castelo de Vide (Andanças, 8th of August), Redondo Town Hall (Tardes Cinéfilas, 4th and 25th of November) and Italy (Lazio 8th of September); and finished in Évora (8th of December). It was inserted in the European Heritage Day 2017 (DGCP) and Portuguese Science Week 2017 (Ciência Viva).
The personal impact of all those film presentations is difficult to measure for citizens. Within the framework of the traditional diffusion and impact (measured through publications in congresses), there are several meters of the festival's public effect: in a local and regional context, for the numerous times that appeared in the press. In addition, another measure of local impact may have already motivated other similar initiatives that reproduce aspects of the Heritales' philosophy, which shows that it is being considered effective. Internationally, by publishing a text with the results presented at the Urban Creativity conference 2017, and that the festival has already been cited in a scientific publication on heritage (Casonato, 2017: 774776). Broadcast networks were also expanded: TV, radio, newspapers, newsletters, and a critique selected as slider on the international Open Edition scientific platform Hypotheses (Zozaya, 2017). Thanks to our partners the DRCA and the CIDEHUS-UÉ, the festival appeared in the main regional and international media. It achieved a greater extension of the information on an national and international level, expanding different ways of dissemination.

An important part to increase the impact of the festival was the call for films proposing the UNESCOUÉ Chair awards. While in the first edition Heritales experimented by inviting all the authors, in 2017 it introduced a more conventional formula of "competition with awards". For this occasion, it purposely created a new prize offered by the UNESCO-UÉ Chair. This consisted in two sculptures made by the renowned artist Pedro Fazenda (Fig. 28), which were awarded to the best long and medium length documentary (Swamp Dialogues; Idilko Plajas, Romania) and the best short documentary (Next Stop: La latina, Begoña Amaranoya, Spain).

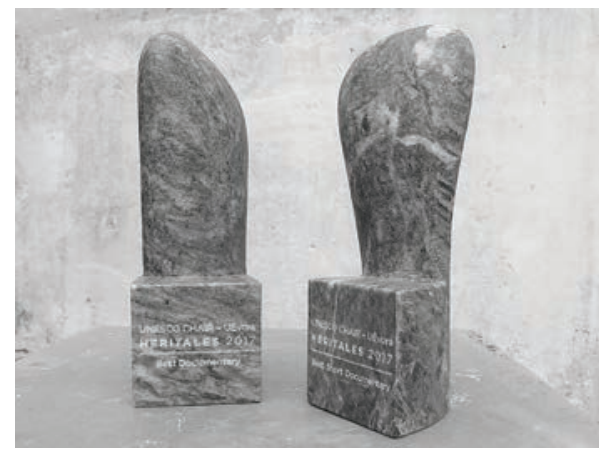

Figure 28 - Heritales 2017 Awards trophies by Pedro Fazenda.

The award ceremony was held in Praça Sertorio (Fig. 29) in front of the City Hall with all the filmmakers and invited authorities and counted with a recognized international jury (José Luis García Sánchez by GONA, Maile Colbert; Ricardo Costa; Irene Lustzig; Vicente Pérez Herrero by Tiempos Difíciles; Diego Cano Gardoqui by Cine Casablanca Valladolid) and 
from the Evora University (José Manuel Martins by Cinema Fora dos Leões, José Alberto Ferreira by Coleção B). With those quoted institutions, Heritales continued the strategy of fostering partnerships to involve the environment in CIDEHUS-UÉ cultural scientific policy. It renewed the cited collaborations and consolidated the support of the city's institutions, such as the DRCA and Évora City Hall (CME).

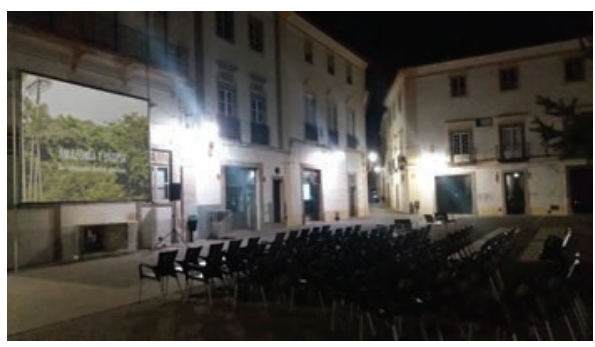

Figure 29 - Final film exhibition in Praça Sertorio.

\section{Conclusions}

Heritales is a new concept of science. It is a festival born with the vocation of showing historical, anthropological, ethnological and cultural heritage material both to the academy and to the public. It is a compendium of screenings, lectures, exhibitions and installations that reveal knowledge about the heritage stored on supports that are not normally considered scientific. The true objective of this project is to study whether this way of disseminating science works for Heritage's transfer of knowledge to the broader audience.

In fact documentaries, films and exhibitions are usually considered to be alien to the academic publications and communication methodologies because they are produced outside the academia and because they are produced in different formats than scientific writings or conferences. However, visual storytelling can be considered one of the most direct way to communicate knowledge to the general public. In this sense Heritales becomes a concept of "urban science" and it tries to take out contents from the university walls and return them to the entire public. It joins public and private enterprises, as a new way to create synergies between cultural heritage and actual ways of development and it tries to do so by leaving the traditional circuit of film exhibitions, projecting or displaying in representative architectures of industrial heritage (walls, palaces), religious (churches, convents), corporate (historical associations) as well as general public social spaces. Heritales 2017 was inserted in the main axis of the strategy of CIDEHUS-UÉ, as a forum for international scientific characterization, an object of interdisciplinary cultural study and in particular within the purposes of its UNESCO Chair to communicate central issues about heritage. It is especially framed within the modern academic tendencies to look for more direct ways of transmitting scientific knowledge. In short, the International Heritage Film Festival - Heritales deepened in the field of the transfer of scientific results through different languages that exist besides the articles of impact and endogamies of the conferences in the academic world. From this experience we aim to propose and comprehend the needs of opening new frontiers for scientific, historical and anthropological communication based on the fact that cinema and other related visual art form are a powerful tool to expand these frontiers and escape from the entanglement that the academia has generated within itself in this last century. We believe that this is only possible by making its discourse available to everyone, by using a universal visual language and by trying to transforms the traditional concept of academic leisure into modern "edutainment".

Heritales 2017 was funded by CIDEHUS - UID/ HIS/00057/2013 (POCI-01-0145-FEDER-007702).

\section{Endnotes}

${ }^{1} \mathrm{PhD}$ (Spain). Researcher FCT ORCID : 0000-0003-07371843, mzozayam@yahoo.es

(Italy) HERITAS [PhD] Estudos de Património [PD/00297/2013] ORCID : 0000-0001-5013-6641, nic@ heritales.org

\section{List of institutional abbreviations with web reference}

CATEDRA-UNESCO UÉvora - Unesco Chair in Intangible Heritage and Traditional Know-How Linking Heritage University of Évora. http://www.catedra.uevora. pt/unesco/

CIDEHUS - Centro Interdisciplinar de História, Culturas e Sociedades (Interdisciplinary Center for History, Cultures and Societies, Portugal). http://www.cidehus.uevora.pt/

CMB - Câmara Municipal de Beja (City Hall of Beja, Portugal). http://www.cm-beja.pt

CME - Câmara Municipal de Évora (City Hall of Évora, Portugal). http://www.cm-evora.pt

CMR - Câmara Municipal de Redondo (C. H. of Redondo, Portugal). http://www.cm-redondo.pt

DGCP - Direção Geral do Património Cultural (General Direction of Cultural Heritage, Portugal) http://www. patrimoniocultural.gov.pt/en

DRCA - Direção Regional de Cultura Alentejo (Regional Direction of Culture Alentejo, Portugal). http://www.culturaalentejo.pt

FACA - Festa de Antropologia Cinema e Arte (Anthropology Film and Art Fest, Portugal). http://cria. org.pt/wp/event/4a-edicao-da-faca-festa-de-antropologia -cinema-e-arte/

FACC - Fundo de Apoio à Comunidade Científica (Scientific Community Support Fund, Portugal). FCT. Refa 440.02. Proc: 17/1/227. https://www.fct.pt/apoios/facc/ index.phtml.en

FCT - Fundação Ciência e Tecnologia (Science and Technology Foundation, Portugal). https://www.fct.pt

FEA - Fundação Eugénio de Almeida (Eugénio de Almeida Foundation, Portugal). http://www. fundacaoeugeniodealmeida.pt/

GPE - Grupo Pro Évora (Pro Évora Group, Portugal). http://www.pro-evora.org 
ISPRA Istituto Superiore per la Protezione e la Ricerca Ambientale (Higher Institute for the Protection and Environmental Research, Italy). http://www.isprambiente. gov.it

SNIMar Sistema Nacional de Informação do Mar (National Information System of the Sea, Portugal). http:// www.snimar.pt/

SHE - Sociedade Harmonia Eborense (Harmonia Eborense Society, Portugal). https://www.facebook.com/ sociedadeharmoniaeborense/

UNESCO - United Nations Educational, Scientific and Cultural Organization, Internation-al) https://en.unesco.org/

\section{List of mentioned institutions, associations and partners}

Belas Artes Lisboa - https://www.ulisboa.pt/en/unidadeorganica/faculty-fine-arts

Ciência Viva, Lisboa - http://cienciaviva.pt/home/

Coleção B, Évora - https://www.facebook.com/ colb2000/

Divinus, Évora- http://divinus.pt/

Grupo Pro Évora - http://www.pro-evora.org/pt/

Estrela D' Ouro, Évora - https://www.facebook.com/ Caf\%C3\%A9-Estrela-dOuro-152137124923427/

Fer Carnes, Évora - http://www.fercarnes.pt

Faculty of Fine Art UL Lisbon - https://www.ulisboa.pt/ en/unidade-organica/faculty-fine-arts

Péde Xumbo, Andanças, - http://www.andancas. net/2018/pt/

Residência Cisterciense - São Bento de Castris, Évora. http://residenciacisterciense.weebly.com/

Vinhos do Alentejo - http://www.vinhosdoalentejo.pt/

\section{Bibliography}

Amiar, Souphiène. 2015. ProjeT ExdipuS [online] Available at: https://sites.google.com/site/wwwedipuscom/ home [Accessed 23 March. 2018].

Agulhon, Maurice. 1968. Pénitents et Francs-Maçons de I'ancienne Provence. Essai sur la sociabilité méridionale. Paris Fayard.

Agulhon, Maurice. 1977. Le Cercle dans la France Bourgeoise, 1810-1848. Étude d'une mutation de sociabilité. París: Flammarion.

Álvarez Luis .P. 2012. La Masonería, Escuela de formación del ciudadano, Univ. Comillas, ( $\left.4^{\mathrm{a}} \mathrm{Ed}\right)$.

Bourdieu, Pierre. 1989. La distinction: critique sociale du jugement. Paris: Minuit.

Barroso, Anna. 2016. Transitions. [online] Available at: http://www.mosteirobatalha.gov.pt/pt/index.php?s=noticias \&noticia=228\#n2 [Accessed 1 Jan. 2018].

Capel S. Horacio. 1983. Ciencia para la burguesía: renovación pedagógica y enseñanza de la geografía en la revolución liberal española. 1817-1854. Barcelona: Universidad.

Capelo, 2016. Eborae Guide Tour. APP by CIDEHUS, https://play.google.com/store/apps/details?id=pt.alentapp. jleitao.eborae_guide_tour

Casonato, Camila. 2017. Intangible perspectives in tangible Heritage, in Giuseppe Amoruso (Ed), Putting Tradition into Practice: Heritage, Place and Design. Collection: Lecture Notes in Civil Engineering, Milan, Springer, pp. 737-745. ISBN 978-3-319-57937-5.

Colbert, M. 2015. Past, Pass, Pasting in Viseu Rural 2.0. http://binauralmedia.org/news/en/arquivo/8235. Accessed on 23-III-2018.
Dicheva, Darina \& Dichev, Christo \& Agre, Gennady \& Angelova, Galia. 2015. Gamification in Education: A Systematic Mapping Study. Educational Technology \& Society, 18 (3), 11-19.

Dosse, François. 1988. La Historia en Migajas. De Annales a la Nueva Historia. Valencia: Alfons el Magnanim.

Dosse, François. 1995. L'empire du sens: l'humanisation des sciences humaines. Paris : La decouverte.

Dumazedier, Joffre. 1964. Hacia una civilización del ocio. Tortosa: Estela.

Estudio Crua, 2016. Som dos Sinos. [online] Available at: http://somdossinos.com.br/ . Accessed on 23-III-2018].

Espanca, Túlio. 1966. Invetario Artistico de Portugal. Academia Nacional das Belas Artes Conselho de Évora Vol. VII. Lisboa.

Febvre, Lucien. 1952. Combats pour l'histoire. Paris: Armand Colin.

Grazia, Sesbastian. 1966. Tiempo, trabajo y ocio, (trad. Vázquez de Parga, Consuelo). Madrid: Tecnos, https:// crowdreciclyng.wordpress.com/2017/06/12/earth-festheritales-cine-de-patrimonio-biologico-en-un-parquenatural/ - https://teartres.wordpress.com/2017/06/13/ heritales-proyecta-en-la-casa-animal/

Huizinga, Johan. 1972. Homo Ludens.- Madrid-Buenos Aires: Alianza Editorial.

Hughes, Gabriel. 2017. Indigenous video games, copyright, and the protection of traditional knowledge. In Mol, A.A.A., Ariese-Vandemeulebroucke, C.E., Boom, K.H.J., Politopoulos, A. (Eds.), 2017. The Interactive past: archaeology, heritage \& video games. Sidestone Press, Leiden. 33-51.

Kuhn, Thomas S. 2001. El camino desde la estructura: ensayos filosóficos, 1970-1993, Conant, James y Haugeland, John (comps). Barcelona: Paidós; 131 a 148.

Lafargue, Paul. 1983. El derecho a la pereza [1880 y 1883]. Pérez Ledesma, Manuel (Ed. crítica). Barcelona: Fundamentos.

Matos Ana C, 2016. Eborae Guide Tour. APP by CIDEHUS, https://play.google.com/store/apps/ details?id=pt.alentapp.jleitao.eborae_guide_tour

Mansur, Marcia \& Thomé Marina. 2016. Som do Sinos [online] Available at: http://somdossinos.com.br/filme/ [Accessed 01 March. 2018].

Miranda T. C. P. dos Reis, 2016. Eborae Guide Tour. APP by CIDEHUS, [Accessed 01 March. 2018]. https:// play.google.com/store/apps/details?id=pt.alentapp.jleitao. eborae_guide_tour

Pérez Herrero, Vicente. Amazonia y Utopia 2016. [online] Available at: http://www.tiemposdificilesfilms.com/ amazonia-y-utopia/ [Accessed 23 March. 2018].

Pieper, Joseph. 1962. El ocio y la vida intelectual, (trads. Alberto Pérez Masegosa et alii). Madrid: Eds Rialp.

Schiavottiello, Nicola \& Zozaya-Montes, Maria. 2017. "Heritales: The Film Festival That Brings Heritage to the Urban Environment." Street, Art \& Urban Creativity Journal, Intangible Heritage, 3 (1): 89-94. https:// www.urbancreativity.org/uploads/1/0/7/2/10727553/ journal2017_v3_n1_final2_web.pdf

Schiavottiello Nicola \& Zozaya-Montes Maria. \& Sarantopoulus, Takis. 2017. Construir um público cultural e científico através do cinema. Heritales como proposta fílmico-académica. Heritales Session with Tardes Cinéfilas (Org. Takis Sarantopoulus), in: Auditório do CCR, Redondo. 4 November 2017.

Schiavottiello Nicola. 2017. Colori Profondi del Mediterraneo. Documentario ISPRA. Heritales - Festival Internazionale del Cinema del Patrimonio Cinema + 
debate, 8 Set. 2017, Riserva Naturale di Tor Caldara (Anzio-Roma). http://www.parchilazio.it/torcaldara-ricerca_ media

Schiavottiello Nicola. 2017. Heritales - No Andanças. Presentation of: Flamenco de Raiz - Vicente Pérez Herrero http://www.tiemposdificilesfilms.com/flamenco-de-raiz/ 8th Aug. 2018 Castelo De Vide Portugal http://www.andancas. net/2017/pt/prog/2680/

Schiavottiello Nicola. 2017. Presentation of the ProjecT OEdipuS. Heritales - teatro e patrimonio. Theather performance by Amiar Souphienne, Igreja de São Vicente, Évora. 6-7 December 2017. http://www.cidehus.uevora.pt/ atividades/noticias/(item)/23471

SNIMar \& Sardinha em Lata. Adescoberta dos Oceanos 2016. http://www.snimar.pt/index.php?page=2\& menu=4\&sub=49 Accessed on 4-02-2018. http:// www.sardinhaemlata.com/adescobertadosoceanos 49 Accessed on 4-02-2018.

Stott, Andrew \& Neustaedter, Carman. 2013. Analysis of Gamification in Education, Technical Report 2013-0422-

01, Connections Lab, Simon Fraser University, Surrey, BC, Canada, April, 1-8.

Thompson, Edouard P. 1989. Folklore, antropología e historia social, en Historia Social, n 3 pp. 90-93.

Veblen, Thorstein. 1899. Teoría de la clase ociosa (trad. Vicente Herrero). Mexico: Fondo de Cultura Económica, 1974 (1 ${ }^{\text {a }}$ ed.).

Zozaya-Montes, Maria. 2017a. Earth Fest + Heritales = Cine de patrimonio biológico en un bosque urbano. CrowdRecycling, ISSN 2444-7285, 12-06-2017.

Zozaya-Montes, Maria. 2017b. Heritales proyecta en la casa animal: cine en espacios patrimoniales. Teartres, Teatro y Artes Contemporáneas, ISSN 2444-7475, 13-062017.

Zozaya-Montes, Maria. 2017c. Tu madre se lee tus artículos? Heritales, o cómo difundir ciencia en una pantalla. Sociabilidad y élites, ISSN 2444-8052, 17-8-2017 https://sociabilidad.hypotheses.org/1216.

Zozaya-Montes, Maria. 2014. ¿Ocio amurallado? El paso de la sociabilidad local al mundo asociativo internacional. Dos casos comparados: Évora-Madrid (1789-1929), Bidebarrieta, 25. ISSN: 1137-4888.

Zozaya-Montes, Maria. 2008. Ocio Liberado. El ocio en España durante el siglo XIX. In: El descubrimiento del Ocio. Guipúzcoa, Diputación Foral: Museo Zumalacárregui. 3365.

Zozaya-Montes, Maria. 2015. Identidades en juego. Formas de representación social del poder de la élite en un espacio de sociabilidad masculino (1836-1936). Madrid: Siglo XXI.

Zozaya-Montes, Maria \& Sarantopoulus Takis. 2017. Significado de Heritales no Sul de Portugal: mostra de cinema e património Cultural universal. Heritales session with Tardes Cinéfilas, in: Auditorio do Centro Cultural de Redondo, CCR Redondo (Portugal). 25 November 2017. Ciência Viva, Semana da Ciência de Portugal 2017: http:// bit.ly/2hvlYh5

Zozaya-Montes, Maria. 2017. Heritales, cinema para promover patrimonios materiales e immateriales religiosos. Transitions by Ana Barroso, Residencia Cisterciense, Refeitório São Bento de Castris, Évora (Portugal). 15 September 2017.

Zozaya-Montes, Maria. 2017d. Heritales Singing another brick in the Wall of the Academia, in IGNITE Criar, Sonhar e Impactar. Fórum FEA,12 dezembro 2017, Évora (Portugal).

\section{Press release}

[Article] "Curtas do Heritales - International Film Festival no auditório do Centro Cultural de Redondo". Diário do Sul. 25-11-2017. https://www.diariodosul.com.pt/noticias/ principal/2393-curtas-do-heritales-international-filmfestival-no-auditorio-do-centro-cultural-de-redondo.html Acedido em 6-06-2019.

[Article] "Destaque: HERITALES - II Encontro Internacional - Festival de Cinema sobre o Património", Direção Geral de Cultura do Alentejo (página web). 2407-2017. http://www.cultura-alentejo.pt/destaques,0,4634. aspx . Accessed on 6-06-2019.

[Article] "Evora recebe festival internacional de cinema Tribuna Alentejo". https://www.tribunaalentejo.pt/artigos/ evora-recebe-festival-internacional-de-cinema Accessed on 6-06-2019.

[Article] "Évora recebe festival internacional de cinema". Tribuna Alentejo. 05-09-2017. https://www.tribunaalentejo. pt/artigos/evora-recebe-festival-internacional-de-cinema . Accessed on 6-06-2019.

[Article] "Festival de Cinema de Património com mais de 20 filmes". Sapo24. 20-09-2017. https://24.sapo.pt/vida/ artigos/festival-de-cinema-de-patrimonio-com-mais-de-20filmes . Accessed on 6-06-2019.

[Article] "Festival de Cinema Heritales arranca sob o tema "Comunidades Sustentáveis"'. E-Cultura Sapo (página web). s/d. http://www.e-cultura.sapo.pt/ evento/6526. Accessed on 6-06-2019.

[Article] "Internacional Film Festival - HERITALES". Município de Redondo (página web). 6-06-2017. http:// www.cm-redondo.pt/pt/site-acontece/Eventos/Paginas/ Internacional-Film-Festival---HERITALES.aspx . Accessed on 6-06-2019.

[Article] "Mais de 20 filmes exibidos em Évora no Festival de Cinema de Património", Diário de Noticias. 20-09-2017. https://www.dn.pt/lusa/interior/mais-de-20-filmes-exibidosem-evora-no-festival-de-cinema-de-patrimonio-8783904. html . Accessed on 6-06-2019.

[Article] "Mais de 20 filmes exibidos em Évora no Festival de Cinema de Património". Jogo on line. 20-092017. https://www.ojogo.pt/extra/lusa/interior/mais-de-20filmes-exibidos-em-evora-no-festival-de-cinema-depatrimonio-8783907.html . Acdessed on 6-06-2019.

[Article] "Mais de 20 filmes exibidos em Évora no Festival de Cinema de Património". Cultura ao minuto. 2009-17. https://www.noticiasaominuto.com/cultura/867358/ mais-de-20-filmes-exibidos-em-evora-no-festival-decinema-de-patrimonio . Accessed on 6-06-2019.

[Article] "O 2. ${ }^{\circ}$ HERITALES - Festival Internacional de Cinema de Património começa na quinta-feira". Sapo Mag. 20-09-2017 https://mag.sapo.pt/cinema/atualidadecinema/artigos/festival-de-cinema-de-patrimonio-levamais-de-20-filmes-a-evora . Accessed on 6-06-2019.

[Article] "Ė aperta fino al 30 Maggio la chiamata per l'edizione 2017 di Heritales - International Heritage Film Festival". Taxidriver (redazione). 9-05-2017. https:// www.taxidrivers.it/91340/festival/aperta-al-30-maggio-lachiamata-ledizione-2017-heritales-international-heritagefilm-festival.html. Accessed on 6-06-2019. 